Research article

\title{
Reduction of post injury neointima formation due to I $7 \beta$-estradiol and phytoestrogen treatment is not influenced by the pure synthetic estrogen receptor antagonist ICI I 82,780 in vitro Gerald Finking*1, Christina Lenz ${ }^{2}$, Thomas Schochat ${ }^{1}$ and Hartmut Hanke ${ }^{2}$
}

Address: ${ }^{1}$ Institute of Occupational, Social, and Environmental Medicine, University of Ulm, Ulm, Germany and ${ }^{2}$ Department of Cardiology, University of Ulm, Ulm, Germany

E-mail: Gerald Finking* - gerald.finking@medizin.uni-ulm.de; Christina Lenz - christina.lenz@medizin.uni-ulm.de; Thomas Schochat - thomas.schochat@medizin.uni-ulm.de; Hartmut Hanke - hartmut.hanke@medizin.uni-ulm.de

${ }^{*}$ Corresponding author

Published: 6 August 2002

BMC Cardiovascular Disorders 2002, 2:13

This article is available from: http://www.biomedcentral.com/I47I-226I/2//3

(C) 2002 Finking et al; licensee BioMed Central Ltd. This article is published in Open Access: verbatim copying and redistribution of this article are permitted in all media for any non-commercial purpose, provided this notice is preserved along with the article's original URL.

Keywords: vascular injury, 17ß-estradiol, phytoestrogens, ICI 182,780, estrogen receptor
Received: 28 May 2002

Accepted: 6 August 2002

\begin{abstract}
Background: Animal and organ culture experiments have shown beneficial inhibitory estrogen effects on post injury neointima development. The purpose of this study was to investigate whether such estrogen effects are influenced by the estrogen receptor antagonist ICI 182,780. Different concentrations of $17 \beta$-estradiol and the phytoestrogens genistein and daidzein were tested.

Methods: $\mathrm{F}$ emale New Zealand White rabbits were benumbed. In situ vascular injury of the thoracic and abdominal aorta was performed by a $3 \mathrm{~F}$ Fogarty catheter. Segments of $5 \mathrm{~mm}$ were randomised and held in culture for $2 I$ days. Three test series were performed: I) control group $20 \mu \mathrm{M} \mathrm{ICl}-30 \mu \mathrm{M} \mathrm{ICl}-40 \mu \mathrm{M} \mathrm{ICl}$. 2) control group $-20 \mu \mathrm{M} \mathrm{ICl}-40 \mu \mathrm{M}$ I $7 \beta$-estradiol $-40 \mu \mathrm{M}$ I7 $\beta$-estradiol $+20 \mu \mathrm{M} \mathrm{ICl}$. 3) control group $-20 \mu \mathrm{M} \mathrm{ICl}-40 \mu \mathrm{M}$ daidzein $-40 \mu \mathrm{M}$ daidzein +20 $\mu \mathrm{M} \mathrm{ICl}-20 \mu \mathrm{M}$ genistein $-20 \mu \mathrm{M}$ genistein $+20 \mu \mathrm{M} \mathrm{ICl}$. After $2 \mathrm{I}$ days the neointima-media-ratio was evaluated.

Results: I) Treatment with ICI 182,780 did not reduce neointima formation significantly $(p=0.05)$. 2) $40 \mu \mathrm{M} \mathrm{I} 7 \beta$-estradiol alone $(\mathrm{p}<0.000 \mathrm{I})$ and in combination with $20 \mu \mathrm{M} \mathrm{ICl}(\mathrm{p}<0.000 \mathrm{I})$ reduced neointima formation significantly. 3) $20 \mu \mathrm{M}$ genistein alone $(p=0.0083)$ and combined with $20 \mu \mathrm{M}$ $\mathrm{ICl}(\mathrm{P}=0.0053)$ reduced neointima formation significantly. $40 \mu \mathrm{M}$ daidzein did not have a significant $(p=0.0637)$ effect.

Conclusions: The estrogen receptor antagonist $\mathrm{ICl} 182,780$ did not modulate the inhibitory estrogen effects on post injury neointima formation. These results do not support the idea that such effects are mediated by vascular estrogen receptors.
\end{abstract}

\section{Background}

Beneficial estrogen effects in the cardiovascular system are still under investigation and have been discussed contro- versially [1-3]. Clinical benefits such as the reduction of cardiovascular mortality, as suggested by several retrospective studies, $[4,5]$ have not been supported by ran- 
domised [6] and interventional $[7,8]$ trials. However, there are plenty of experimental data demonstrating beneficial estrogen effects on distinct aspects of the cardiovascular system, i.e., lipid metabolism [9] and lipid peroxidation [10], post injury smooth muscle cell and neointimal proliferation [11-14], and the vascular tone [15-18]. Some of these effects are also described for phytoestrogens like genistein and daidzein which therefore may be suggested as a possible therapeutic option in postmenopausal women [19].

In previous organ culture experiments we have demonstrated that $17 \beta$-estradiol and the phytoestrogens genistein (with) [20] and daidzein (without protein tyrosine kinase activity) [21] were able to inhibit neointima formation after vascular injury in a dose dependent manner $[22,23]$. These effects have been described in aortic rings not only from female but from male rabbits as well [24]. In further experiments we titrated the lowest concentrations of these three estrogens which were able to reduce neointima formation significantly and we moreover demonstrated that this effect was unlikely caused by toxicity [25].

The aim of this present in vitro study was to investigate whether the inhibitory estrogen effect on post injury neointima development is modulated by estrogen receptor dependent pathways. Such interactions have been demonstrated and postulated since estrogen receptors were detected in the vasculature of animals [26] and humans $[27,28]$. The description of different subtypes of the estrogen receptor (estrogen receptor $\alpha$ and $\beta$ ) led to more speculations on cardiovascular estrogen effects in animals and humans as well [1,29-32]. We therefore wanted to investigate whether the pure synthetic estrogen receptor antagonist 7 alpha- [9-(4,4,5,5,5-pentafluoropentylsulfinyl) nonyl]estra 1,3,5(10)-triene-3,17 beta-diol (ICI 182,780) [33] can modulate vascular estrogen effects.

\section{Methods}

\section{In vitro model}

A total of 7 mature female New Zealand White (NZW) rabbits (Tierforschungszentrum, University of Ulm, Germany) were benumbed by shooting a bolt into the back of their heads and exsanguinated by cutting their carotid arteries. The abdomen was opened with a scalpel and the aortic vessel prepared by removal of the connective tissue. Endothelium denudation of the abdominal and thoracic aorta was then performed in all animals in situ with a $3 \mathrm{~F}$ Fogarty catheter (Baxter Inc., Unterschleissheim, Germany) which was pushed into the vessel through an incision at the iliac bifurcation. After inflation with natrium chloride $0.9 \%$ the balloon was pulled through the whole vessel one time. The now denuded aortas were excised by saving the adventitial tissue. Each aorta was cut into sec- tions of $5 \mathrm{~mm}$ and these aortic rings were randomised into 14 groups. Three experimental test series were performed (Table 1): 1) Effect of the pure synthetic estrogen receptor antagonist ICI 182,780 (Schering, Berlin, Germany) at concentrations of 20,30 and $40 \mu \mathrm{M}(\mathrm{n}=8$ each). 2) Effect of $40 \mu \mathrm{M} 17 \beta$-estradiol (Sigma, Deisenhofen, Germany) alone and in combination with $20 \mu \mathrm{M}$ ICI 182,780 , the lowest concentration having been found to have no effect on neointimal proliferation in test series $1(\mathrm{n}=12 \mathrm{each})$. 3) Effect of $40 \mu \mathrm{M}$ Daidzein (Sigma, Deisenhofen, Germany) and $20 \mu \mathrm{M}$ Genistein (Sigma, Deisenhofen, Germany) alone and combined with $20 \mu \mathrm{M}$ ICI 182,780 ( $\mathrm{n}=10$ each). These concentrations of $17 \beta$-estradiol, Genistein and Daidzein have been demonstrated to be the lowest concentrations with an inhibitory effect on neointima formation previously (Figure 1) [25].

Control groups were held in medium containing $1 \%$ isopropanol (Roth, Karlsruhe, Germany) and 1\% dimethyl sulphoxide (DMSO) (Sigma, Deisenhofen, Germany) because $17 \beta$-estradiol, Genistein and Daidzein were dissolved in isopropanol and DMSO of the same concentration. All aortic rings were held separately in sixwell plates for 21 days at $37^{\circ} \mathrm{C}$ with phenol red free Dulbecco's modified Eagle medium (DMEM) with Ham's F12 (mixed 1 plus 4; Gibco, Eggenstein, Germany), containing D-glucose $(4.5 \mathrm{~g} / \mathrm{l}), 15 \%$ fetal calf serum (fcs) (Bio Whittacker, Heidelberg, Germany) and 2,5 ml/l PenicillinStreptomycin (Gibco, Eggenstein, Germany). The medium contained $1 \%$ isopropanol and $1 \%$ DMSO in all groups and was renewed together with the estrogens three times a week.

After 21 days of treatment the sections were rinsed with PBS buffer (Dulbecco's PBS, Gibco, Eggenstein, Germany), $500 \mathrm{ml}$ PBS buffer containing $5 \mathrm{ml} \mathrm{PBS}+$ basic-solution with calcium chloride dihydrate an magnesium chloride hexahydrate (Sigma, Deisenhofen, Germany).

\section{Immunohistochemistry, morphometry, statistical evaluation}

The sections were fixed in $4 \%$ formaline, embedded in paraffin, and serially cut ( $4 \mu \mathrm{m}$ slices) until the maximal thickness of the neointima was reached. Haemalaun and Eosin staining was performed for a first morphological analysis. To identify smooth muscle cells and myofibroblasts among medial and neointimal cells immunohistochemical staining (biotin avidin peroxidase method) was performed with a monoclonal antibody against $\alpha$-actin (mouse-anti-human; Renner Inc, Darmstadt, Germany). Elastica-van-Gieson's staining was performed for the morphometry of the neointima and media (software package from Bilaney Consulting Inc, Düsseldorf, Germany). The neointimal area was defined the area between lamina elastica interna and lumen. The media area was defined 


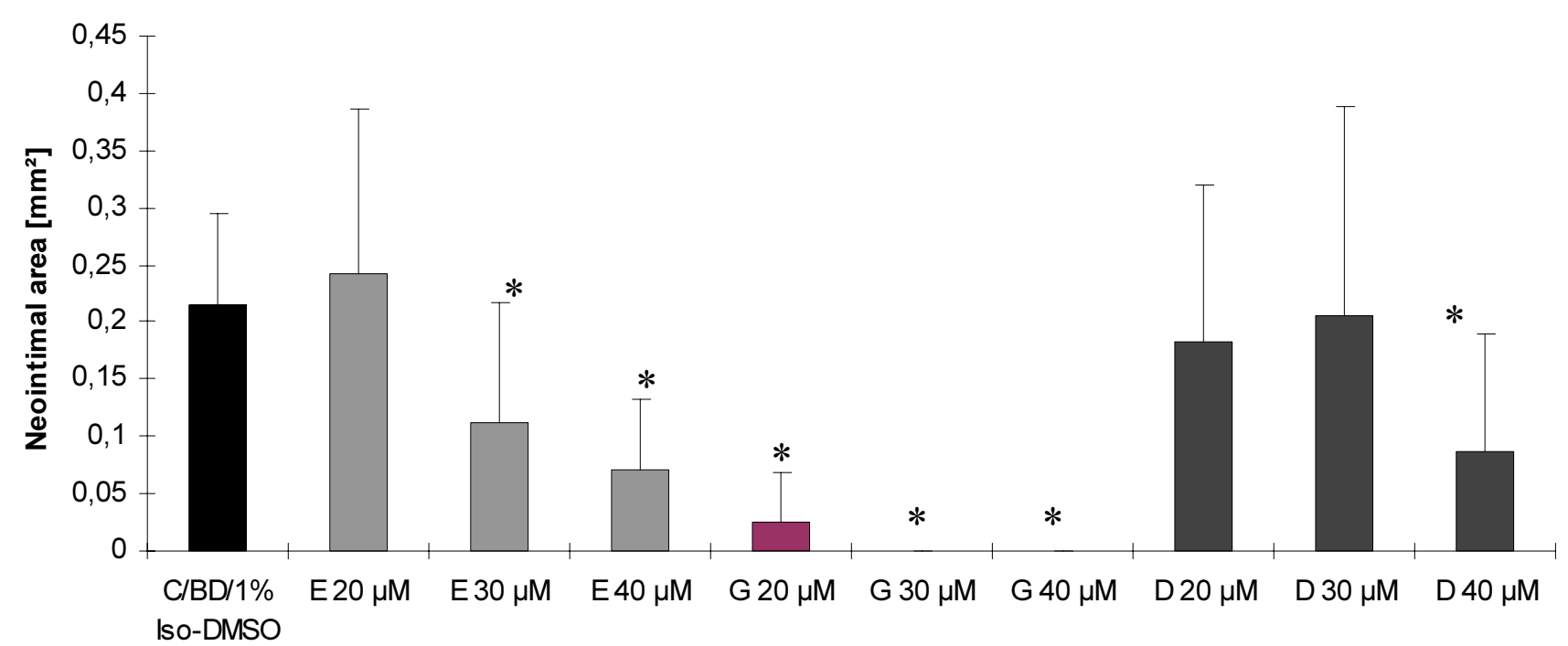

Estrogen/phytoestrogen treated groups

Figure I

Inhibitory effect of $17 \beta$-estradiol (E), genistein (G) and daidzein (D) on post-injury neointima development in concentrations of 20/30/40 $\mu \mathrm{M}$, compared to endothelium balloon denuded (BD) controls (C) (mean \pm SD). The medium of all groups contained I \% isopropanol (I \% iso) and I \% DMSO. Compared with controls I7 $\beta$-estradiol, genistein, and daidzein (*) reduced neointima formation significantly $(p=0.05)$ in a concentration dependent manner. Data from Finking et al., 2000 [25].

Table I: Study Protocol

\begin{tabular}{|c|c|c|c|}
\hline Goup & Ist series & $2^{\text {nd }}$ series & $3^{\text {rd }}$ series \\
\hline Control & Control group & Control group & Control group \\
\hline Treatment & $20 \mu \mathrm{M} I C I \quad 82,780$ & $20 \mu \mathrm{M} \mathrm{ICI} 182,780$ & $20 \mu \mathrm{MICl} I 82,780$ \\
\hline Treatment & $30 \mu \mathrm{M}$ ICI I82,780 & $40 \mu \mathrm{M}$ 17 $\beta$-estradiol & $20 \mu \mathrm{M}$ genistein \\
\hline Treatment & $40 \mu \mathrm{M} I C I I 82,780$ & $40 \mu \mathrm{M}$ I7 $\beta$-estradiol $+20 \mu \mathrm{M} \mathrm{ICI} \mid 82,780$ & $20 \mu \mathrm{M}$ genistein $+20 \mu \mathrm{M} \mathrm{ICI} 182,780$ \\
\hline Treatment & & & $40 \mu \mathrm{M}$ daidzein \\
\hline Treatment & & & $40 \mu \mathrm{M}$ daidzein $+20 \mu \mathrm{M} \mathrm{ICI} 182,780$ \\
\hline
\end{tabular}

the area between lamina elastica interna and externa. Histomorphometry was done in a blinded fashion. The effect on neointima formation is expressed as the neointima/ media ratio (median and 1 st $/ 3^{\text {rd }}$ quartile). The Wilcoxon two-sample test was used to determine statistical significance at a level of $p=0.05$.

\section{Results}

\section{Morphoplogical aspects}

Aortic rings were morphologically intact after 21 days of cultivation and treatment as seen by microscopy. The lamina elastica interna and externa was intact as well. The media area (area between lamina elastica interna and externa) contained vascular smooth muscle cells which were made visible by $\alpha$-actin staining. Sections had different amounts of neointima formation that contained vasculars mooth muscle cells surrounded by connective tissue (Figure 2).

\section{Effect of ICI I82,780 on post injury neointima formation} Administration of ICI 182,780 in concentrations of 20, 30 and $40 \mu \mathrm{M}$ did not cause a significant $(\mathrm{p}=0.05)$ effect on post injury neointima formation (neointima/media-ratio) over 21 days (Figure 3). Regarding the highest concentration of $40 \mu \mathrm{M}$ ICI 182,780 treatment the p-value did only reach 0.0875 which was in part due to the wide range of the measured data. 


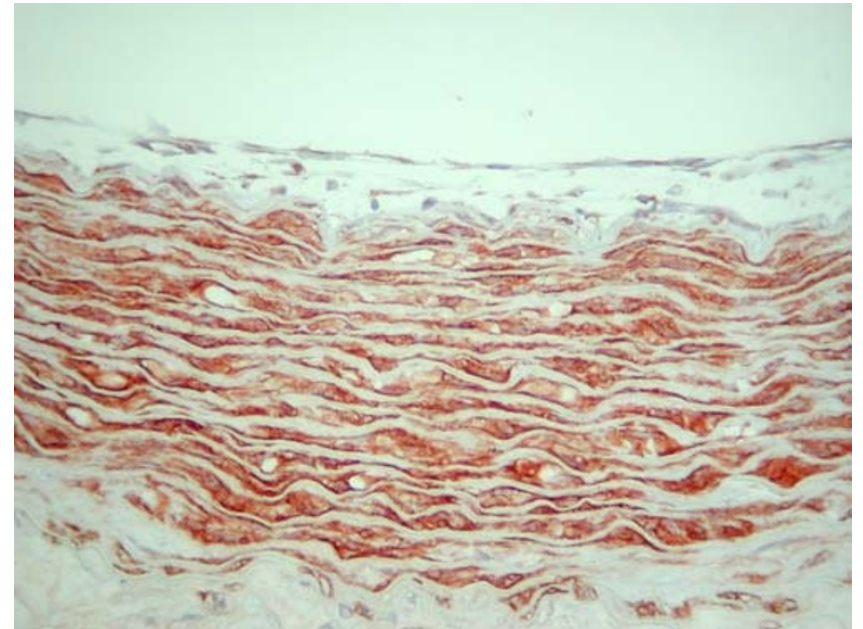

Figure 2

Example for neointima formation in a female rabbit aortic section after endothelial balloon denudation and 21 days of cultivation in medium containing I \% isopropanol and I \% DMSO. Staining with $\alpha$-actin, magnification by lens $\times 20$. Vascular smooth muscle cells are stained in the medial tissue and in the neointima.

Effect of $17 \beta$-estradiol on post injury neointima formation Treatment with $40 \mu \mathrm{M} 17 \beta$-estradiol over 21 days (Figure 4 ) resulted in a significant $(\mathrm{p}<0.0001)$ reduction of post injury neointima formation (neointima/media-ratio). Treatment with $20 \mu \mathrm{M}$ ICI 182,780 alone did not have an effect. Additional treatment of $20 \mu \mathrm{M}$ ICI 182,780 with 40 $\mu \mathrm{M} 17 \beta$-estradiol treatment did not result in a significant reduction of the $17 \beta$-estradiol effect.

\section{Effect of the phytoestrogens genistein and daidzein on post injury neointima formation}

Treatment with $20 \mu \mathrm{M}$ Genistein resulted in a significant $(\mathrm{p}=0.0083)$ reduction of post injury neointima formation (neointima/media-ratio) after 21 days (Figure 5). This effect was not modulated by additional treatment with $20 \mu \mathrm{M}$ ICI 182,780. However, treatment with $40 \mu \mathrm{M}$ daidzein did not result in a statistically significant neointima formation $(\mathrm{p}=0.0637)$ in this experiment. Additional treatment with $20 \mu \mathrm{M}$ ICI 182,780 also did not cause a significant effect.

\section{Discussion}

The purpose of this in vitro experiment was to investigate whether inhibitory estrogen and phytoestrogen effects on post injury neointima formation, as demonstrated previously [22-25], can be influenced by the pure synthetic estrogen receptor antagonist ICI 182,780. Because aortic rings from the whole aortic tree were used as target organs and because the lumen diameter varies between different aortas and parts of the aortic tree (thoracic and abdominal aorta), the neointima-/media-ratio was calculated as the basis for statistical analysis. In a first step the effect of different ICI 182,780 dosages from $20 \mu \mathrm{M}$ to $40 \mu \mathrm{M}$ was tested. These dosages corresponded to estrogen and phytoestrogen dosages that had been established as effective in this organ culture model before [25]. ICI 182,780 treatment in the three dosages did not cause a significant effect on post injury neointima formation (neointima-/ media ratio). Focussing on neointima formation independent from the media area (data not shown) there was a statistically significant $(\mathrm{p}=0,0392)$ inhibitory effect at a concentration of $40 \mu \mathrm{M}$ ICI 182,780 . Because it has been shown previously that ICI 182,780 at concentrations $>50$ $\mu \mathrm{M}$ directly affects the metabolism of $17 \beta$-estradiol it did not make sense to use higher concentrations in this experiment [34]. In order to investigate possible interactions between an inhibitory estrogen/phytoestrogen effect on post injury neointima formation and the estrogen receptor antagonist, we used the lowest $20 \mu \mathrm{M}$ concentration of ICI 182,780 as tested before. Treatment with $40 \mu \mathrm{M} 17 \beta$ estradiol resulted in a significant reduction/inhibition of post injury neointima formation. This inhibitory effect was not influenced or modulated by additional treatment with $20 \mu \mathrm{M}$ ICI 182,780.

Treatment with $20 \mu \mathrm{M}$ genistein reduced post injury neointima formation significantly. This inhibitory effect could not be influenced by additional treatment with 20 $\mu \mathrm{M}$ ICI 182,780 . The concentration of $40 \mu \mathrm{M}$ daidzein did not have an inhibitory effect on post injury neointima formation, although this was demonstrated in previous ex-

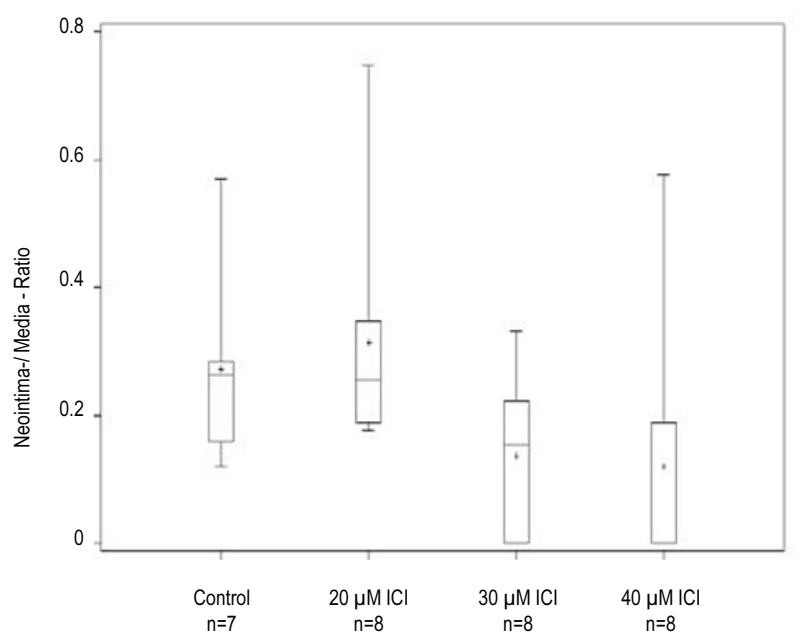

Figure 3

The pure estrogen receptor antagonist $\mathrm{ICl} 182,780$ in concentrations from $20 \mu \mathrm{M}$ to $40 \mu \mathrm{M}$ did not have a significant effect $(p=0.05)$ on post injury neointima formation. Skeletal Box-and-Whisker Plot showing (top down) maximum, $3^{\text {rd }}$ percentile, mean, median, Ist percentile and minimum. 
periments [25]. While a weak tendency of an inhibitory effect was visible in this present experiment, speculations may be allowed on the effect of higher concentrations of daidzein. Additional treatment with $20 \mu \mathrm{M}$ ICI 182,780 did not influence the daidzein effect.

Genistein is well investigated as an inhibitor of protein tyrosine kinases $[20,21]$. This may account for estrogen receptor independent antiproliferative properties. Genistein's analogue daidzein lacks tyrosine kinase activity which could explain the different effects in our experiment $[21,35,36]$.

On the base of this presented data the inhibitory estrogen effect of both, $17 \beta$-estradiol and the phytoestrogens, is unlikely mediated by estrogen receptor pathways. Our data support observations from experiments with female mice which were deficient of one of the two known estrogen receptor (ER) subtypes $\alpha$ or $\beta$. Physiologic levels of $17 \beta$-estradiol, when compared with ovariectomized animals, were able to reduce neointimal proliferation after vascular injury in both, ER-a [37] and ER- $\beta$ [38] deficient mice. Moreover, our data support findings from Dubey et al. who demonstrated that phytoestrogens like genistein and daidzein were able to inhibit human aortic smooth muscle cell proliferation and migration by estrogen receptor independent, i. e., mitogen-activated protein (MAP-) kinase modulated pathways [39]. The authors, too, used the synthetic ICI 182,780 for their control experiments. ICI 182,780 was first introduced by Wakeling et al. [33]

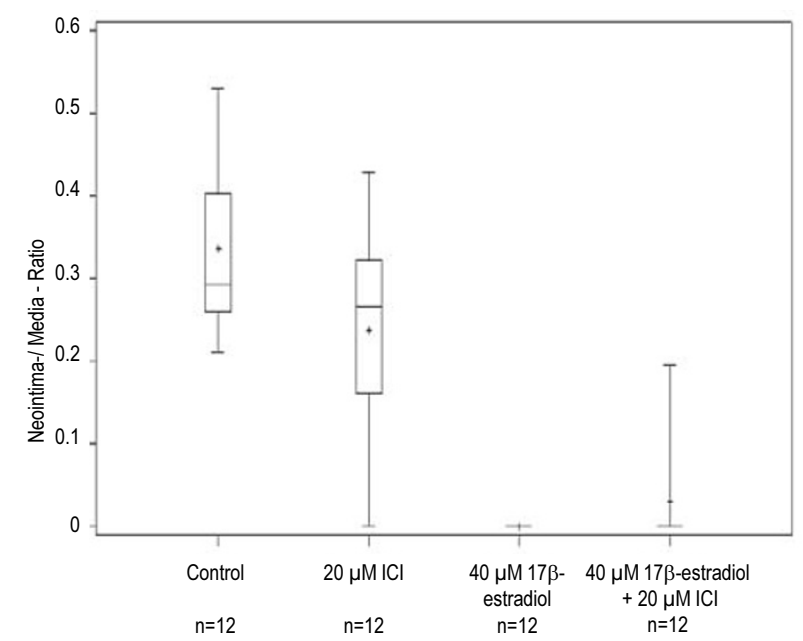

Figure 4

I7 $\beta$-estradiol in a concentration of $40 \mu \mathrm{M}$ caused a significant $(p<0.000 \mathrm{I})$ inhibition of post injury neointima development. This effect was not modulated by additional treatment with $20 \mu \mathrm{M}$ of the pure antiestrogen ICI 182,780. Skeletal Boxand-Whisker Plot showing (top down) maximum, $3^{\text {rd }}$ percentile, mean, median, I $^{\text {st }}$ percentile and minimum.

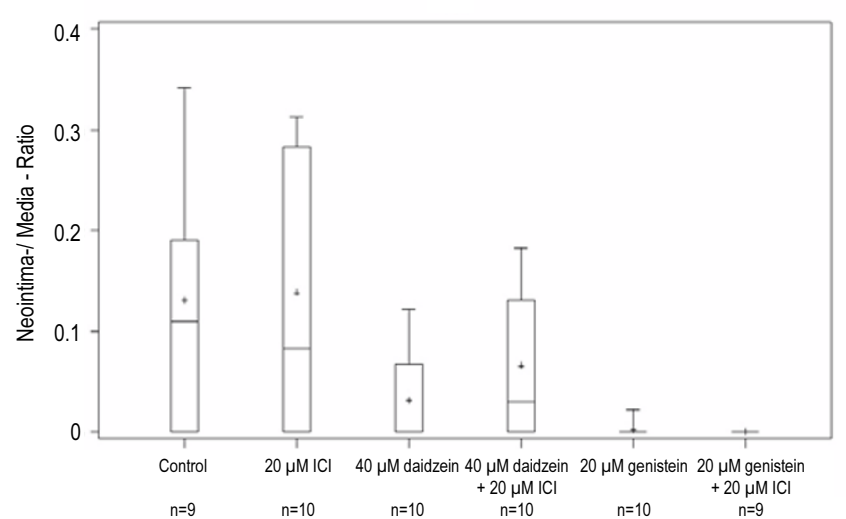

Figure 5

Treatment with genistein $20 \mu \mathrm{M}(\mathrm{p}=0.0083)$ but not with daidzein $40 \mu \mathrm{M}(\mathrm{p}=0.0637)$ caused a significant inhibition of post injury neointima formation. Additional treatment with $20 \mu \mathrm{M}$ of the pure antiestrogen $\mathrm{ICl} 182,780$ did not have a significant $(p=0.05)$ modulating effect. Skeletal Box-andWhisker Plot showing (top down) maximum, $3^{\text {rd }}$ percentile, mean, median, I $^{\text {st }}$ percentile and minimum.

and has been characterized as a competitive antagonists to estrogens with high affinity to the estrogen receptor and without a significant estrogenic activity itself.

But our data is in contrast to previous in vivo findings from Bakir et al. [40]. The authors demonstrated an inhibitory ICI 182,780 effect on $17 \beta$-estradiol induced reduction of post injury neointima formation in rat carotid arteries. However, another organ culture experiment (pulmonary arteries from hypoxic rats) by Karamsetty et al. demonstrated that $10 \mu \mathrm{M} 17 \beta$-estradiol, $30 \mu \mathrm{M}$ genistein, and $30 \mu \mathrm{M}$ daidzein enhanced the relaxation response to carbachol. This was found to be a result of increased nitric oxide synthesis and release. But this effect could not be mediated by additional treatment with $10 \mu \mathrm{M}$ ICI 182,780 [41]. The authors used estrogen and ICI 182,780 at concentrations comparable to our experiment. New findings on slow genomic (transcriptional) and rapid nongenomic (i.e., MAP kinase) estrogen effects [39,42,43] and on different estrogen receptor subtypes (estrogen receptor $\alpha$ and $\beta$ ) [1-3] may lead to deeper insights into the pharmacology of this system. Quite subtle ICI 182,780 effects on estrogen receptors could be demonstrated in specific cells of the sheep uterus [44] and in yeast genetic systems [45]. The acute and rapid estrogen induced calcium-dependent release of NO could be blocked by ICI 182,780 in bovine aortic endothelial cells [46] and in a human vascular endothelial cell (HUVEC) system [47].

The question remains which estrogen receptor independent mechanism(s) may have led to the demonstrated in- 
hibitory estrogen/phytoestrogen effect on post injury neointima formation in our present experiment. Dubey et al. were able to demonstrate that not $17 \beta$-estradiol but endogenous metabolites like methoxyestradiols, with no affinity to estrogen receptors, could be responsible for ERindependent antimitogenic effects on vascular smooth muscle cells [48]. Metabolites like 2-methoxyestradiol and 2-hydroxyestradiol were more potent than was $17 \beta$ estradiol in inhibiting DNA synthesis, collagen synthesis, cell proliferation and migration [34]. Cytochrome-P450 played a key role in this local estrogen metabolism and ICI 182,780 at concentrations $>50 \mu \mathrm{M}$ inhibited this metabolism. In addition, other nongenomic, i.e., antioxidant mechanisms have to be discussed. Yoon at al. demonstrated inhibitory $17 \beta$-estradiol effects on vascular smooth muscle cell proliferation (VSMC from rats) induced by lysophosphatidylcholine (component of oxidized LDL) or reactive oxygen species (ROS) [49]. The inhibitory $17 \beta$ estradiol effect was not antagonized by ICI 182,780 . Furthermore, calcium antagonistic gender independent properties have been described for $17 \beta$-estradiol $[15,16]$ and for several phytoestrogens [50].

\section{Conclusions}

The inhibitory effect of $17 \beta$-estradiol and the phytoestrogen genistein on post injury neointima formation has unlikely been mediated by estrogen receptor dependent pathways.

\section{Competing interests}

None declared.

\section{Author's contributions}

G.F. planned the studies, drafted the manuscript. C.L. carried out the studies. T.S. participated in the design of the study and performed statistic analyses. H.H. conceived the studies and participated in its design and coordination.

\section{Acknowledgements}

Processing of this organ culture model was supported by a grant from the ZEBET (Zentralstelle zur Erfassung und Bewertung von Ersatz- und Ergänzungsmethoden zum Tierversuch) in Berlin. The authors thank the Schering AG in Berlin which provided the ICI I82,780.

\section{References}

I. Mendelsohn ME, Karas $\mathrm{RH}$ : The protective effects of estrogen on the cardiovascular system. N Engl | Med 1999, 340: |80|-|8| |

2. Finking G, Gohar MH, Lenz C, Hanke H: Die Wirkungen von Ostrogen im kardiovaskularen System. Z Kardiol 2000, 89:442-453

3. Finking G, Gohar MH, Lenz C, Hanke H: Cardiovascular oestrogen effects in women. J Obstet Gynaecol 200 I, 2 I:340-349

4. Sullivan JM, Vander-Zwaag R, Hughes JP, Maddock V, Kroetz FW, Ramanathan KB, Mirvis DM: Estrogen replacement and coronary artery disease. Effect on survival in postmenopausal women. Arch Intern Med 1990, I 50:2557-2562

5. Grodstein F, Stampfer MJ, Colditz GA, Willett WC, Manson JE, Joffe M, Rosner B, Fuchs C, Hankinson SE, Hunter DJ, Hennekens CH, Speizer FE: Postmenopausal hormone therapy and mortality. N EnglJ Med 1997, 336:I769-I775

6. Hulley S, Grady D, Bush T, Furberg C, Herrington D, Riggs B, Vittinghoff E: Randomized trial of estrogen plus progestin for sec- ondary prevention of coronary heart disease in postmenopausal women. Heart and Estrogen/progestin Replacement Study (HERS) Research Group. Jama 1998, 280:605-613

7. O'Brien JE, Peterson ED, Keeler GP, Berdan LG, Ohman EM, Faxon DP, Jacobs AK, Topol EJ, Califf RM: Relation between estrogen replacement therapy and restenosis after percutaneous coronary interventions. J Am Coll Cardiol 1996, 28: I I I I-I I I8

8. O'Keefe JH, Kim SC, Hall RR, Cochran VC, Lawhorn SL, McCallister BD: Estrogen replacement therapy after coronary angioplasty in women. J Am Coll Cardiol 1997, 29:1-5

9. Anonymous: Effects of estrogen or estrogen/progestin regimens on heart disease risk factors in postmenopausal women. The Postmenopausal Estrogen/Progestin Interventions (PEPI) Trial. The Writing Group for the PEPI Trial. Jama 273:199-208

10. Sack MN, Rader DJ, Cannon RO: Oestrogen and inhibition of oxidation of low-density lipoproteins in postmenopausal women. Lancet 1994, 343:269-270

II. Vargas R, Wroblewska B, Rego A, Hatch J, Ramwell PW: Oestradiol inhibits smooth muscle cell proliferation of pig coronary artery. Br J Pharmacol 1993, 109:612-617

12. Krasinski K, Spyridopoulos I, Asahara T, van-der-Zee R, Isner JM, Losordo DW: Estradiol accelerates functional endothelial recovery after arterial injury. Circulation 1997, 95: I768-I772

13. Chen SJ, Li H, Durand J, Oparil S, Chen YF: Estrogen reduces myointimal proliferation after balloon injury of rat carotid artery. Circulation 1996, 93:577-584

14. Oparil S, Chen SJ, Chen YF, Durand JN, Allen L, Thompson JA: Estrogen attenuates the adventitial contribution to neointima formation in injured rat carotid arteries. Cardiovasc Res 1999, 44:608-6/4

15. Jiang C, Poole-Wilson PA, Sarrel PM, Mochizuki S, Collins P, MacLeod KT: Effect of I 7 beta-oestradiol on contraction, Ca2+ current and intracellular free $\mathrm{Ca2}+$ in guinea-pig isolated cardiac myocytes. Br J Pharmacol 1992, 106:739-745

16. Jiang CW, Sarrel PM, Lindsay DC, Poole-Wilson PA, Collins P: Endothelium-independent relaxation of rabbit coronary artery by 17 beta-oestradiol in vitro. Br J Pharmacol I991, I 04:10331037

17. Gilligan DM, Quyyumi AA, Cannon RO: Effects of physiological levels of estrogen on coronary vasomotor function in postmenopausal women. Circulation 1994, 89:2545-255 I

18. Gilligan DM, Badar DM, Panza JA, Quyyumi AA, Cannon RO: Acute vascular effects of estrogen in postmenopausal women. Circulation 1994, 90:786-79|

19. Finking $G$, Hess $B$, Hanke $H$ : The value of phytoestrogens as a possible therapeutic option in postmenopausal women with coronary heart disease. J Obstet Gynaecol 1999, 19:455-459

20. Akiyama T, Ishida J, Nakagawa S, Ogawara H, Watanabe S, Itoh N, Shibuya M, Fukami Y: Genistein, a specific inhibitor of tyrosinespecific protein kinases. J Biol Chem 1987, 262:5592-5595

21. Bisch of G, Illek B, Reenstra WW, Machen TE: Role for tyrosine kinases in carbachol-regulated $\mathrm{Ca}$ entry into colonic epithelial cells. Am J Physiol 1995, 268:CI54-I6I

22. Finking $G$, Lenz $C$, Wohlfrom $M$, Hanke $H$ : In vitro Modell zur Untersuchung der Wirkung von ostrogenen auf die Neointimabildung nach Endothelverletzung an der Kaninchenaorta. Altex 2000, I7: I - | 4

23. Finking G, Wohlfrom M, Lenz C, Wolkenhauer M, Eberle C, Brehme $U$, Bruck B, Hanke H: The effect of I Tbeta-estradiol, and the phytoestrogens genistein and daidzein on neointima development in endothelium-denuded female rabbit aortae-an in vitro study. Endothelium 2000, 7:99-107

24. Finking G, Wohlfrom M, Lenz C, Wolkenhauer M, Eberle C, Hanke $\mathrm{H}$ : The phytoestrogens Genistein and Daidzein, and 17 betaestradiol inhibit development of neointima in aortas from male and female rabbits in vitro after injury. Coron Artery Dis 1999, 10:607-615

25. Finking G, Wolkenhauer $M$, Lenz $C$, Hanke $H$ : Post-injury ex vivo model to investigate effects and toxicity of pharmacological treatment in rings of rabbit aortic vessels. Altex 2000, I 7:67-74

26. Lin AL, McGill HC, Shain SA: Hormone receptors of the baboon cardiovascular system. Biochemical characterization of aortic and myocardial cytoplasmic progesterone receptors. Circ Res 1982, 50:610-616 
27. Karas RH, Patterson BL, Mendelsohn ME: Human vascular smooth muscle cells contain functional estrogen receptor. Circulation 1994, 89:1943-1950

28. Venkov $C D$, Rankin $A B$, Vaughan DE: Identification of authentic estrogen receptor in cultured endothelial cells. A potential mechanism for steroid hormone regulation of endothelial function. Circulation 1996, 94:727-733

29. Kuiper GG, Enmark E, Pelto-Huikko M, Nilsson S, Gustafsson JA: Cloning of a novel receptor expressed in rat prostate and ovary. Proc Natl Acad Sci U S A 1996, 93:5925-5930

30. Grohe C, Kahlert S, Lobbert K, Vetter H: Expression of oestrogen receptor alpha and beta in rat heart: role of local oestrogen synthesis. J Endocrinol 1998, I 56:RI-7

31. Grohe C, Kahlert S, Lobbert K, Stimpel M, Karas RH, Vetter H, Neyses L: Cardiac myocytes and fibroblasts contain functiona estrogen receptors. FEBS Lett 1997, 41 6:107-I I2

32. Mosselman S, Polman J, Dijkema R: ER beta: identification and characterization of a novel human estrogen receptor. FEBS Lett 1996, 392:49-53

33. Wakeling AE, Dukes M, Bowler J: A potent specific pure antiestrogen with clinical potential. Cancer Res I99 I, 5 I:3867-3873

34. Barchiesi F, Jackson E-K, Gillespie D-G, Zacharia L-C, Fingerle J, Dubey R-K: Methoxyestradiols mediate estradiol-induced antimitogenesis in human aortic SMCs. Hypertension 2002, 39:874-879

35. Jonas JC, Plant TD, Gilon P, Detimary P, Nenquin M, Henquin JC: Multiple effects and stimulation of insulin secretion by the tyrosine kinase inhibitor genistein in normal mouse islets. $\mathrm{Br}$ Pharmacol 1995, I | 4:872-880

36. Negrescu EV, de-Quintana KL, Siess W: Platelet shape change induced by thrombin receptor activation. Rapid stimulation of tyrosine phosphorylation of novel protein substrates through an integrin- and $\mathrm{Ca}(2+)$-independent mechanism. Biol Chem 1995, 270:1057-106I

37. lafrati MD, Karas RH, Aronovitz M, Kim S, Sullivan TR Jr, Lubahn DB, O'Donnell TF Jr, Korach KS, Mendelsohn ME: Estrogen inhibits the vascular injury response in estrogen receptor alpha-deficient mice. Nat Med 1997, 3:545-548

38. Karas RH, Hodgin JB, Kwoun M, Krege JH, Aronovitz M, Mackey W, Gustafsson JA, Korach KS, Smithies O, Mendelsohn ME: Estrogen inhibits the vascular injury response in estrogen receptor beta-deficient female mice. Proc Natl Acad Sci U S A 1999 , 96: $15133-15136$

39. Dubey RK, Gillespie DG, Imthurn B, Rosselli M, Jackson EK, Keller PJ: Phytoestrogens inhibit growth and MAP kinase activity in human aortic smooth muscle cells. Hypertension 1999, 33:177182

40. Bakir S, Mori T, Durand J, Chen YF, Thompson JA, Oparil S: Estrogen-induced vasoprotection is estrogen receptor dependent: evidence from the balloon-injured rat carotid artery model. Circulation 2000, 10 1:2342-2344

4I. Karamsetty MR, Klinger JR, Hill NS: Phytoestrogens restore nitric oxide-mediated relaxation in isolated pulmonary arteries from chronically hypoxic rats. J Pharmacol Exp Ther 2001 , 297:968-974

42. Wade CB, Robinson S, Shapiro RA, Dorsa DM: Estrogen receptor (ER)alpha and ERbeta exhibit unique pharmacologic properties when coupled to activation of the mitogen-activated protein kinase pathway. Endocrinology 200I, | 42:2336-2342

43. Van-Den-Bemd GJ, Kuiper GG, Pols HA, Van-Leeuwen JP: Distinct effects on the conformation of estrogen receptor alpha and beta by both the antiestrogens ICI I64,384 and ICI I82,780 leading to opposite effects on receptor stability. Biochem Biophys Res Commun 1999, 26 I:1-5

44. Robertson JA, Zhang $Y$, Ing $\mathrm{NH}$ : ICI I 82,780 acts as a partial agonist and antagonist of estradiol effects in specific cells of the sheep uterus. J Steroid Biochem Mol Biol 200 I, 77:28I-287

45. Dudley MW, Sheeler CQ, Wang H, Khan S: Activation of the human estrogen receptor by the antiestrogens ICI I82,780 and tamoxifen in yeast genetic systems: implications for their mechanism of action. Proc Natl Acad Sci U S A 2000, 97:3696-370 I

46. Goetz RM, Thatte HS, Prabhakar P, Cho MR, Michel T, Golan DE: Estradiol induces the calcium-dependent translocation of endothelial nitric oxide synthase. Proc Natl Acad Sci U S A 1999 , 96:2788-2793
47. Russell KS, Haynes MP, Sinha D, Clerisme E, Bender JR: Human vascular endothelial cells contain membrane binding sites for estradiol, which mediate rapid intracellular signaling. Proc Natl Acad Sci U S A 2000, 97:5930-5935

48. Dubey RK, Gillespie DG, Zacharia LC, Rosselli M, Korzekwa KR, Fingerle J, Jackson EK: Methoxyestradiols mediate the antimitogenic effects of estradiol on vascular smooth muscle cells via estrogen receptor-independent mechanisms. Biochem Biophys Res Commun 2000, 278:27-33

49. Yoon BK, Oh WJ, Kessel B, Roh CR, Choi D, Lee JH, Kim DK: I 7 Beta-estradiol inhibits proliferation of cultured vascular smooth muscle cells induced by lysophosphatidylcholine via a nongenomic antioxidant mechanism. Menopause 200I, 8:5864

50. Chiang CE, Chen SA, Chang MS, Lin Cl, Luk HN: Genistein directly inhibits L-type calcium currents but potentiates cAMP-dependent chloride currents in cardiomyocytes. Biochem Biophys Res Commun 1996, 223:598-603

\section{Pre-publication history}

The pre-publication history for this paper can be accessed here:

http://www.biomedcentral.com/1471-2261/2/13/prepub

Publish with BioMed Central and every scientist can read your work free of charge

"BioMedcentral will be the most significant development for disseminating the results of biomedical research in our lifetime."

Paul Nurse, Director-General, Imperial Cancer Research Fund

Publish with BMC and your research papers will be:

- available free of charge to the entire biomedical community

- peer reviewed and published immediately upon acceptance

- cited in PubMed and archived on PubMed Central

- yours - you keep the copyright 